Stilovi učenja i utjecaj na promjenu životnih navika Learning strategies and their impact on changing lifestyle habits

\section{Ljiljana Broz*}

Škola za medicinske sestre Mlinarska, Zagreb, Hrvatska School of Nursing Mlinarska, Zagreb, Croatia
RECEIVED:

February 20, 2017

ACCEPTED:

February 28, 2017

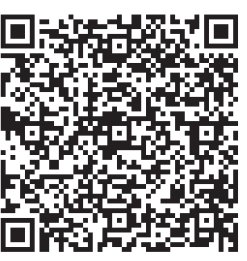

KLJUČNE RIJEČI: životne navike, stilovi učenja, kvaliteta života

KEYWORDS: lifestyle habits, learning strategies, quality of life.

CITATION: Cardiol Croat. 2017;12(3):91. | DOI: http://dx.doi.org/10.15836/ccar2017.91

*ADDRESS FOR CORRESPONDENCE: Ljiljana Broz, Škola za medicinske sestre Mlinarska, Mlinarska 34, HR-10000 Zagreb, Croatia. / Phone: +385-1-4668-079 / Fax: +385-1-4668-494 / E-mail: Ijiljana_broz@yahoo.com ORCID: Ljiljana Broz, http://orcid.org/0000-0002-7728-0894

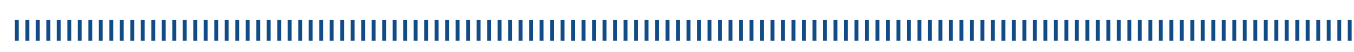

Arterijska hipertenzija predstavlja vodeći javnozdravstveni problem. Način života (loše prehrambene navike, pretilost, neadekvatna tjelesna aktivnost, povećan unos alkohola, pušenje, stres) i neadekvatno liječenje predstavljaju čimbenike rizika koji doprinose razvoju bolesti¹. Posljedično nastaju brojne komplikacije koje dovode do značajnog narušavanja zdravlja i kvalitete života. Promjene životnih navika pomažu u kontroli arterijskog tlaka i sprečavanju nastanka komplikacija. Cilj ovog rada je upoznati stilove učenja i povećati mogućnosti utjecaja na promjene životnih navika.

Usvajanje zdravstveno odgojnih sadržaja utječe na promjene u ponašanju. Dovodi do očuvanju zdravlja i sprečava napredovanja već postojeće bolesti. Rezultat je poboljšanje kvalitete života, veće zadovoljstvo oboljelih i bolja suradnja.

Obzirom da sve osobe nisu jednake i načini poučavanja tijekom edukacije bi trebali biti raznoliki, odnosno prilagođeni mogućnostima i sposobnostima pojedinca kojeg se educira. Bitna je procjena socijalne zrelosti (odgovornosti za vlastito zdravlje)2 $)^{2}$ Stil učenja je dominantni ulazni kanal kod prijema i obrade informacija, odnosno najuspješniji način usvajanja zdravstveno odgojnih sadržaja. Dobro je procijeniti stil učenja, ali i osobitost svakog oboljelog koji će biti sudionik edukacije. Preporuka je učenje gledanjem, slušanjem i pokretom/aktivnošću (vizualno, auditivno i kinestetičko), odnosno uporaba VAK teorije ${ }^{3}$. Jedan od instrumenata je upitnik za procjenu stilova učenja (VAK upitnik)4. Edukaciju treba organizirati na način kako bi se usvojeno znanje moglo prilagoditi svakodnevnom životu, više puta ponavljati te utjecati na mijenjanje životnih navika. Vizualni stil učenja uključuje učenje u slikama, ilustracije, film, grafikone ${ }^{3}$. Dobro je naglasiti i izdvojiti dio teksta (pismene upute), koristiti boje i crteže. Bitna je i dobra organizacija. Auditivni (verbalni) stil učenja uključuje govor, rasprave i izlaganja, uključuje ponavljanje i naglašavanje određenih pojmova. Kinestetički stil učenja (pokret ili aktivnost) usmjeren je na izvođenje određenih zadataka. Nakon provedbe edukacije preporuka je dati zadatak i aktivno uključiti sudionike u izradu materijala za edukaciju, a nakon izvedbe zadatka procijeniti uspješnost edukacije. $^{4}$

Ako koristimo istovremeno više stilova učenja, ishodi edukacije postaju uspješniji. Poznavanjem osobina određenih stilova učenja, uz dobru procjenu osoba koje se educiraju, može se u kraćem vremenu puno više utjecati na usvajanje i razumijevanje zdravstveno odgojnih sadržaja, samih terapijskih postupaka, te promjenu ponašanja. Slušanjem se zapamti $10 \%$ onog što čitamo, gledanjem i slušanjem 50 \%, a ono što čujemo, vidimo, izgovorimo i učinimo usvojeno je $90 \%$.

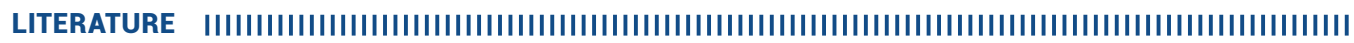

1. Marasović Šušnjara I. Javnozdravstveno značenje hipertenzije. Nastavni zavod za javno zdravstvo Splitsko-dalmatinske županije. 2013;11-19. Dostupno na: http://www.nzjzsplit.hr/userfiles/Zajedno_do_zdravlja Pristup: 30.01.2017.

2. Matijević M. Radovanović D. Nastava usmjerena na učenika. Zagreb. Školske novine. 2011.

3. Borić E. Metodika visokoškolske nastave. Osijek. Sveučilište Josipa Jurja Strossmayera u Osijeku, 2013.

4. Agencija za strukovno obrazovanje i obrazovanje odraslih. Andragoški modeli poučavanja, priručnik za rad s odraslim polaznicima, Modul I, Dostupno na: www.asoo.hr/userdocsimages/andragoski modeli poučavanja. Pristup: 30.1.2017. 